\title{
PENETAPAN PERDA KAWASAN LINDUNG SEBAGAI SALAH SATU TINDAKAN PREVENTIF UNTUK MENCEGAH BANJIR
}

\author{
Tony Hanoraga
}

\begin{abstract}
Abstrak
Masalah banjir adalah masalah yang menyangkut lingkungan hidup. Terjadinya masalah lingkungan merupakan akumulasi dari berbagai faktor penyebab yang sangat luas dan komplek. Berbagai faktor penyebab tersebut dapat dibagi dalam dua kelompok yaitu faktor penyebab yang bersifat alamiah (yang menyangkut kondisi serta peristiwa alam), dan adanya pengaruh/campur tangan manusia yang bermukim dan melakukan berbagai kegiatan di daerah aliran sungai (DAS) baik di bagian hulu, tengah maupun di hilir.

Pengendalian banjir dapat dikategorikan berdasarkan kriteria-kriteria yang terdiri dari pendangkalan sungai, pengelolaan DAS, aliran permukaan, daerah resapan, perilaku masyarakat dan reklamasi pantai sedangkan alternatif pemecahannya berdasarkan perencanaan tata ruang, reboisasi dan teknologi pengendalian. Berdasarkan alternatif perencanaan tata ruang, reboisasi dan teknologi pengendalian menunjukkan bahwa perencanaan tata ruang mempunyai prioritas yang paling baik sebesar 55,0 \% dilanjutkan reboisasi sebesar 29,3\% dan yang terakhir adalah teknologi pengendalian sebesar 15,8\%. Dalam perencanaan tata ruang yang terpenting penetapan kawasan lindung.

Kawasan Lindung adalah Kawasan yang ditetapkan dengan fungsi utama melindungi kelestarian lingkungan hidup yang mencakup sumber alam, sumber daya buatan dan nilai sejarah serta budaya bangsa guna kepentingan pembangunan berkelanjutan. Penetapan kawasan lindung bertujuan untuk mencegah timbulnya kerusakan fungsi lingkungan hidup guna menjamin terselenggaranya perlindungan sistem penyangga kehidupan dan keselamatan kehidupan yang berkesinambungan.

Kawasan lindung meliputi: a. kawasan yang memberkan perlindungan kawasan bawahannya, b. kawasan perlindungan setampat, c. kawasan suaka alam dan cagar budaya, d. kawasan rawan bencana alam.

Setelah Draft Perda disyahkan menjadi Perda, hal yang tidak kalah penting adalah sosialisasi dan penegakan hukum PERDA itu sendiri. Sosialisasi PERDA akan berdampak pada kesadaran masyarakat terhadap kepatuhan PERDA tersebut, sehingga perbuatan masyarakat akan sesuai dengan harapan (sesuai dengan PERDA). Penegakan hukum amat tergantung dari aparat penegak hukum itu sendiri dan kesadaran masyarakat. Apabila aparat penegak hukumnya disiplin dan penuh dedikasi maka kemungkinan KKN amat kecil dan PERDA akan terasa efektif, sehingga banjir dapat dicegah.
\end{abstract}

Kata kunci: masalah lingkungan, pengendalian banjir, tata ruang, kawasan lindung.

Hujan dan angin kencang masih akan terjadi hingga April di Sumatra,

Jawa, NTB, dan NTT. Kabubdit Mitigasi Bencana Geologi Direktorat Vulkanologi dan Mitigasi Bencana Geologi (DVMBG), Dr Surono, di Bandung, mengatakan sekitar 58 sungai di Pulau Jawa memiliki potensi rawan ancaman 
banjir bandang yang membawa material lumpur seiring tingginya curah hujan. Di Jawa Tengah ada 10 sungai, Jawa Timur 18 sungai, dan Jawa Barat 30 sungai (berita KAI/Kemitraan Air Indonesia, 5 Feb. 2004 - 11:49).

Menurut Kepala Prakiraan Cuaca Badan Meterologi dan Geofisika (BMG) Kota Semarang, Deddy Syarifuddin, kini tengah terjadi pertemuan arus angin utara yang berasal dari Australia menuju Indonesia dengan arus angin selatan yang berasal dari Samudra Hindia dan Laut Jawa. "Secara global, angin utara dan selatan ini berkonvergensi (bertemu) di atas kepulauan Indonesia dan menyebabkan pengaruh rendah yang disebut awan komulonipus, sehingga terjadi badai," ujarnya. Pertemuan dua arus angin itu mengakibatkan terjadinya pergeseran awan dan memunculkan cuaca buruk. Kondisi ini, jelas Deddy, akan berlangsung hingga pertengahan Maret dan April. "Dan daerah yang paling rawan saat ini terjadinya badai adalah Kepulauan Sumatra, sepanjang Pulau Jawa, serta sebagian di NTB dan NTT," ungkapnya (berita KAI/Kemitraan Air Indonesia, 5 Feb. $2004-11: 49)$.

Di Jawa Timur, Rabu tanggal 4 Februari 2004 banjir melanda Kabupaten Mojokerto, Kabupaten Pasuruan, Kabupaten Madiun, Kota Malang, Kota Batu, dan Kabupaten Nganjuk, dengan ketinggian air mencapai satu meter. Satu balita dikabarkan terbawa arus di Kecamatan Gondang, Kabupaten Madiun.

Warga Jawa Timur diminta mewaspadai terjadinya hujan disertai badai yang masih mungkin terjadi di beberapa wilayah di Jawa Timur (Jatim), seperti di Pantai Utara (Pantura) seperti Lamongan, Bojonegoro, dan Gresik, di Pantai Selatan seperti Malang, Trenggalek, Pacitan sampai Banyuwangi, serta di wilayah tengah. Hal itu sesuai dengan pantauan citra satelit oleh BMG Tanjung Perak Surabaya. Potensi hujan disertai badai seperti diungkapkan oleh Kepala BMG Tanjung Perak Surabaya, Edy Waluyo, Selasa (3/2) itu sudah terbukti terjadi di beberapa daerah di Jatim Selasa malam hingga Rabu (4/2) dini hari.

Sesuai dengan perkiraan BMG, curah hujan di atas rata-rata 100 sampai $150 \mathrm{~mm} / \mathrm{hari}$, sementara kondisi normal hanya sekitar $50 \mathrm{~mm} / \mathrm{hari}$. Hal itu membuat Kota Batu dilanda banjir dan tanah longsor, jalan raya SurabayaPasuruan terputus, Waduk Pandankrajan Mojokerto jebol, dan ratusan hektare (ha) 
padi di Bojonegoro terendam (berita KAI/Kemitraan Air Indonesia, 5 Feb. 2004 11:47).

Masalah banjir adalah masalah yang menyangkut lingkungan hidup, dan terjadinya masalah umumnya merupakan akumulasi dari berbagai faktor penyebab yang sangat luas dan komplek. Berbagai faktor penyebab tersebut dapat dibagi dalam dua kelompok yaitu faktor penyebab yang bersifat alamiah (yang menyangkut kondisi serta peristiwa alam), dan adanya pengaruh/campur tangan manusia yang bermukim dan melakukan berbagai kegiatan di daerah aliran sungai (DAS) baik di bagian hulu, tengah maupun di hilir.

Menurut B.J. Pratondo, pengendalian banjir dapat dikategorikan berdasarkan kriteria-kriteria yang terdiri dari pendangkalan sungai, pengeloaan DAS, aliran permukaan, daerah resapan, perilaku masyarakat dan reklamasi pantai sedangkan alternatif pemecahannya berdasarkan perencanaan tata ruang, reboisasi dan teknologi pengendalian. Berdasarkan alternatif perencanaan tata ruang, reboisasi dan teknologi pengendalian menunjukkan bahwa perencanaan tata ruang mempunyai prioritas yang paling baik sebesar 55,0\% dilanjutkan reboisasi sebesar 29,3\% dan yang terakhir adalah teknologi pengendalian sebesar 15,8 \%. Dalam perencanaan tata ruang yang terpenting penetapan kawasan lindung (B.J. Pratondo, 2002:7).

Dalam penetepan Perda Kawasan Lindung ini, yang menjadi permasalahan adalah kawasan mana saja yang perlu lindung dan bagaimana kriterianya, sehingga dapat efektif untuk mencegah banjir.

\section{Landasan Dalam Pembuatan Peraturan Perundang-Undangan}

Suatu peraturan perundang-undangan yang baik menurut $H$. Rosjidi Ranggawidjaja, sekurang-kurangnya harus memiliki tiga landasan, yaitu landasan filosofis, landasan sosiologis, dan landasan yuridis. Tetapi ada yang menambahkannya dengan landasan tehnik perancangan dan landasan politis (1998:43). 


\section{- Landasan Filosofis (Filosofische Grondslag)}

Filsafat atau pandanagn hidup suatu daerah berisi nilai-nilai moral atau etika dari daerah tersebut. Moral dan etika pada dasarnya berisi nilai-nilai yang baik dan yang tidak baik. Nilai yang baik adalah pandangan dan cita-cita yang di junjung tinggi. Di dalamnya ada nilai kebenaran, keadilan, kesusilaan, dan berbagai nilai lainnya yang dianggap baik. Pengertian baik, benar, adil, dan susila tersebut menurut tataran yang dimiliki daerah yang bersangkutan. Semua nilai yang ada di Indonesia terakumulasi dalam Pancasila, karena Pancasila adalah pandangan hidup, cita-cita bangsa, falsafah atau jalan kehidupan (Way of life).

Apapun jenisnya filsafat hidup bangsa, harus menjadi rujukan dalam membentuk hukum yang akan dipergunakan dalam kehidupan bangsa tersebut. Oleh karena itu kaidah hukum yang dibentuk harus mencerminkan filsafat hidup bangsa itu, sekurang-kurangnya tidak bertentangan dengan nilai-nilai moral bangsa.

\section{- Landasan Sosiologis (Sociologische Grondslag)}

Suatu peraturan perundang-undangan dikatakan mempunyai landasan sosiologis apabila ketentuan-ketentuannya sesuai dengan keyakinan umum atau kesadaran hukum masyarakat. Hal ini penting agar perundang-undangan yang dibuat ditaati oleh masyarakat, tidak menjadi kalimat-kalimat mati belaka. Hal ini berarti bahwa peraturan perundang-undangan yang dibuat harus dipahami oleh masyarakat, sesuai dengan kenyataan hidup masyarakat yang bersangkutan. Hukum yang dibentuk harus sesuai dengan "Hukum yang hidup", (Living Law) dalam masyakat. Walaupun demikian tidak berarti bahwa apa yang ada pada suatu saat dan dalam suatu masyarakat akan menjadi nilai kehidupan selanjutnya. Produk perundang-undangan tidak merekam keadaan seketika (Moment opname). Masyarakat berubah, nilai-nilaipun berubah, kecenderungan dan harapan masyarakat harus dapat diprediksi dan terakumulasi dalam peraturan perundang-undangan yang berorientasi masa depan. 


\section{- Landasan Yuridis (Juridische Grondslag)}

Landasan yuridis adalah landasan hukum yang menjadi dasar kewenangan (bevoegdheid, competentie) pembuatan peraturan perundang-undangan. Dasar hukum kewenangan membentuk peraturan perundang-undangan sangat diperlukan. Tanpa disebutkan dalam peraturan perundang-undangan, seorang pejabat atau suatu badan adalah tidak berwenang (onbevoegdheid) mengeluarkan peraturan. Misalnya pasal 69 Undang-Undang Nomor 22 tahun 1999 memberi kewenangan kepada Kepala Daerah menetapkan Peraturan Daerah atas persetujuan DPRD dalam rangka penyelenggaraan Otonomi Daerah. Landasan demikian sering disebut landasan yuridis formal. Didalam landasan yuridis formal selain menetapkan badan yang berwenang membentuk, juga secara garis besar ditetapkan proses dan prosedur penetapannya. Misalnya suatu Peraturan Daerah sebelum ditetapkan oleh Kepala Daerah harus mendapat persetujuan lebih dahulu dari DPRD.

Selain menentukan dasar kewenangan landasan hukum juga merupakan dasar keberadaan atau pengakuan dari suatu jenis peraturan perundang-undangan. Landasan Yuridis demikian disebut landasan yuridis material. Landasan yuridis material menunjuk pada materi muatan tertentu yang harus dimuat dalam suatu peraturan perundang-undangan tertentu, isi atau substansi sustu peraturan perundang-undangan harus sesuai dengan "Wadahnya". Selain itu, isi sustu peraturan perundang-undangan tidak boleh bertentangan dengan isi Peraturan Perundang-Undangan yang derajatnya lebih tinggi.

Menurut Bagir Manan, dasar yuridis sangat penting dalam pembuatan Peraturan Perundang-Undaangan karena akan menunjukkan :

1. Keharusan adanya kewenangan dari pembuat Peraturan PerundangUndangan. Setiap Peraturan Perundang-Undangan harus dibuat oleh badan atau Pejabat yang berwenang.

2. Keharusan adanya kesesuaian bentuk atau jenis Peraturan PerundangUndangan dengan materi uyang diatur, terutama kalau diperintahkan oleh Peraturan Perundang-Undangan yang tingkatnya lebih tinggi atau sederajat. 
3. Keharusan mengikuti tata cara tertentu apabila tata cara tersebut tidak diikuti, Peraturan Perundang-Undangan mungkin batal demi hukum atau tidak / belum mempunyai kekuatan hukum mengikat.

4. Keharusan tidak bertentangan dengan Peraturan Perundang-Undangan yang lebih tinggi tinkatannya.

Selain ketiga landasan tersebut masih terdapat landasan lain yaitu landasan teknik perancangan. Peraturan Perundang-Undangan yang kurang baik dapat juga terjadi karena tisdak jelas perumusannya sehingga tidak jelas arti, maksud dan tujuannya (ambiguous) atau rumusannya dapat ditafsirkan dalam berbagai arti (interpretatif). Atau terjadi inkonsistensi dalam menggunakan peristilahan atau sistematika yang tidak baik, bahasa yang berbelit-belit sehingga sukar dimengeri dan lain sebagainya.

M. Solly Lubis menambahkan satu lagi landasan yaitu landasan politis. Landasan politis ialah garis kebijaksanaan politik yang menjadi dasar selanjutnya bagi kebijaksanaan-kebijaksanaan dan pengarahan ketatalaksanaan pemerintahan negara. Misalnya garis kebijaksanaan politik di bidang otonomi daerah yang tercantum dalam Tap MPR RI No. IV/MPR/2000 Tentang Rekomendasi Kebijakan Dalam Penyelenggaraan Otonomi Daerah, dan PROPERNAS menjadi landasan politis dalam pembuatan Peraturan Daerah ini (1989:8-9).

\section{Azas-Azas Peraturan Perundang-Undangan}

Purnadi Purbacaraka dan Soerjono Soekamto memperkenalkan enam azas Perundang-Undangan, yaitu :

1. Undang-undang tidak berlaku surut;

2. Undang-Undang yang dibuat oleh penguasa lebih tinggi mempunyai kedudukan lebih tinggi pula.

3. Undang-Undang yang bersifat khusus menyampingkan Undang-Undang yang bersifat umum (Lex specialis derogat lex generalis);

4. Undang-Undang yang berlaku belakangan membatalkan Undang-Undang yang berlaku terdahulu (Lex posteriori derogat lex priori);

5. Undang-Undang tidak dapat diganggu gugat; 
6. Undang-Undang sebagai sarana untuk semaksimal mungkin dapat mencapai kesejahteraan sepiritual dan material bagi masyarakat maupun individu melalui pembaharuan atau pelestarian (Azas welvaarstaat) (1979:15-19).

Dalam kaitan ini Amiroeddin Syarif menetapkan adanya lima azas PerundangUndangan yaitu :

1. Azas Tingkatan Hirarki;

2. Undang-Undang tak dapat diganggu gugat;

3. Undang-Undang yang bersifat khusus menyampingkan Undang-Undang yang bersifat umum (Lex specialis derogat lex generalis);

4. Undang-Undang tidak berlaku surut;

5. Undang-Undang yang baru menyampingkan Undang-Undang yang lama (Lex posteriori derogat lex priori) (1987:78-84).

\section{Materi Muatan Peraturan Daerah}

Apakah materi muatan yang dapat diatur dalam Peraturan daerah? Pasal 69 Undang-Undang No. 22 Tahun 1999 menyatakan bahwa Kepala Daerah dengan persetujuan Dewan Perwakilan Rakyat Daerah berwenang menetapkan Peraturan Daerah. Jadi Peraturan Daerah merupakan produk hukum dari Pemerintah Daerah. Keberadaan Pemerintah Daerah (Otonom) adalah dalam rangka pelaksanaan otonomi daerah. Dengan demikian maka Peraturan Daerah adalah produk hukum dalam rangka pelaksanaan otonomi daerah, yaitu dalam rangka melaksanakan hak dan wewenang untuk mengatur dan mengurus urusan rumah tangga daerah. Akhirnya dapat disimpulkan bahwa materi muatan Peraturan Daerah pertama-tama adalah materi yang berkaitan dengan urusan rumah tangga daerah, karena hal-hal yang menjadi urusan rumah tangga daerah diatur oleh daerah sendiri. Pengaturan tersebut dituangkan dalam Peraturan Daerah. Hal-hal yang berkaitan dengan Organisasi Pemenintah Daerah antara lain tentang Sekretariat Derah, Dinas Daerah, Pegawai/ aparatur Daerah, Perusahaan Daerah, Keuangan Daerah dan APBD. 
Hal kedua yang dapat diatur atau menjadi materi muatan Peraturan Daerah adalah hal-hal yang berkaitan dengan urusan tugas pembantuan (medebewind). Mengapa urusan tugas pembantuan harus diatur dengan Peraturan Daerah? Sebagaimana dimaklumi bahwa tugas pembantuan adalah tugas yang diberikan kepada pemerintah daerah. Oleh karena tugas pembantuan diberikan kepada Pemerintah Daerah sementara Pemerintah Daerah sendiri meliputi Kepala Daerah dan Dewan Perwakilan Rakyat Daerah maka pelaksanaan tugas pembantuan harus dilakukan oleh kedua unsur tersebut. Hal-hal yang memerlukan pengaturan lebih lanjut dalam rangka melaksanakan tugas pembantuan harus diatur dengan peraturan yang dibentuk oleh Pemerintah Daerah. Peraturan dimaksud tiada lain adalah Peraturan Daerah dan bukan Keputusan Kepala Daerah.

Dari uraian diatas dapat disimpulkan bahwa meteri muatan Peraturan Daerah da adalah materi yang berhubungan dengan urusan otonomi daerah (desentralisasi) dan materi yang berhubuingan dengan tugas pembantuan.

\section{Proses Pembuatan Perda}

Tahap penyusunan PERDA dapat dirinci menjadi :

- Tahap Persiapan

- Tahap Prakarsa

- Tahap Pembahasan

- Tahap Pengundangan

Bahwa materi atau usul inisiatifnya materi pembahasan Peraturan Daerah tentang Kawasan Lindung ini bisa berasal dari eksekutif atau legislatif. Biasanya usulan yang paling sering berasal dari eksekutif. Setelah semua materi terkumpul (PRA RANCANGAN) kemudian mengajak kerja sama Tim Tehnis untuk membicarakan dan dikoordinasikan dengan instansi terkait lainnya termasuk Bagian Hukum, masyarakat (LSM) dan diadakan pembahasan yang mendalam terhadap penilaian materi serta penyempurnaan terhadap teknik penyusunan peraturan daerah yang menghasilkan RAPERDA.

RAPERDA tersebut kemudian diajukan melalui Bagian Hukum kepada Bupati guna mendapatkan pengantar dan mengajukan ke DPRD. Kemudian 
DPRD dan pihak Eksekutif dengan melibatkan anggota masyarakat yang terkait dan LSM mengadakan pembahasan terhadap RAPERDA tersebut dalam sidangsidang DPRD guna mendapat kesepakatan. Dari proses pembahasan RAPERDA tersebut menghasilkan Peraturan Daerah (PERDA) yang ditetapkan dan ditanda tangani oleh Kepala Daerah serta Ketua DPRD.

PERDA yang bersifat mengatur diundangkan dengan menempatkannya dalam Lembaran Daerah, dan mempunyai kekuatan hukum setelah diundangkan dalam Lembaran Daerah.

\section{Sisgtematika dan Materi Pokok Draft Perda}

Sistematika dari draft perda tentang Kawasan Lindung dapat dijabarkan sebagai berikut:

- JUDUL / NAMA

- KONSIDERAN

- Dasar Sandaran

- Dasar Hukum

- BAB I KETENTUAN UMUM

BAB II TUJUAN DAN SASARAN

BAB III RUANG LINGKUP KAWASAN LINDUNG

BAB IV KRITERIA KAWASAN LINDUNG

BAB V PENGELOLAAN KAWASAN LINDUNG

BAB VI SANKI ADMINISTRASI

BAB VII KETENTUAN PIDANA

BAB VIII KETENTUAN PENYIDIKAN

BAB IX KETENTUAN PERALIHAN

BAB X KETENTUAN PENUTUP

- PENJELASAN

- Penjelasan Umum

- Penjelasan Pasal Demi Pasal 


\section{Materi Pokok Tentang Penetapan Kawasan Lindung}

Kawasan Lindung adalah Kawasan yang ditetapkan dengan fungsi utama melindungi kelestarian lingkungan hidup yang mencakup sumber alam, sumber daya buatan dan nilai sejarah serta budaya bangsa guna kepentingan pembangunan berkelanjutan. Penetapan kawasan lindung bertujuan untuk mencegah timbulnya kerusakan fungsi lingkungan hidup guna menjamin terselenggaranya perlindungan sistem penyangga kehidupan dan keselamatan kehidupan yang berkesinambungan.

Sasaran penetapan kawasan lindung adalah :

a. Meningkatkan fungsi lindung terhadap tanah, air, iklim, tumbuhan dan satwa serta nilai sejarah dan budaya bangsa ;

b. Mempertahankan keanekaaragaman tumbuhan satwa tipe ekosistemnya dan keunikan alam ;

c. Memberikan arahan bagi Badan Hukum dan perorangan dalam merencanakan dan melaksanakan program pembangunan ;

d. Memberikan ketentraman dan keamanan bagi masyarakat generasi sekarang dan yang akan datang.

Berdasarkan Kepres No. 32 Tahun 1990 tentang Pengelolaan Kawasan Lindung, Kawasan lindung meliputi :

a. Kawasan yang memberkan perlindungan kawasan bawahannya ;

b. Kawasan perlindungan setampat ;

c. Kawasan suaka alam dan cagar budaya;

d. Kawasan rawan bencana alam.

Kawasan yang memberikan perlindungan kawasan bawahanya sebagaimana dimaksud diatas, terdiri dari :

a. Kawasan Hutan Lindung ;

b. Kawasan Lindung Lainnya ;

c. Kawasan Resapan Air.

Kawasan perlindungan setempat sebagaimana dimaksud di atas, terdiri dari :

a. Sempadan pantai ;

b. Sempadan sungai ; 
c. Kawasan sekitar waduk/danau ;

d. Kawasan sekitar rawa ;

e. Kawasan sekitar mata air.

Kawasan Suaka Alam Cagar Budaya sebagaimana dimaksud di atas, terdiri dari :

a. Kawasan Suaka Alam ;

b. Kawasan Suaka Alam Laut dan Perairan Lainnya ;

c. Kawasan Pantai Berhutan bakau ;

d. Taman Nasional, Taman Hutan Raya dan Taman Wisata Alam ;

e. Kawasan cagar budaya dan Ilmu Pengetahuan.

Kawasan Rawan Bencana Alam sebagaimana dimaksud di atas, terdiri dari :

a. Kawasan rawan bencana akibat gerakan tanah seperti tanah longsor, gempa bumi ;

b. Kawasan rawan banjir;

c. Kawasan letusan gunung berapi.

\section{Kriteria Kawasan Lindung}

Perlindungan terhadap kawasan hutan lindung dilakukan untuk mencegah terjadinya erosi, bencana banjir, sedimentasi, dan menjaga fungsi hidrologis tanah untuk menjamin ketersediaan unsur tanah, air tanah dan air permukaan.

Kawasan hutan lindung memiliki kriteria sebagai berikut :

1. kawasan hutan dengan faktor - faktor lereng lapangan, jenis tanah marginal, curah hujan tinggi melebihi nilai skor 175 yang rentan terhadap bahaya banjir dan tanah longsor.

2. kawasan hutan yang mempunyai ketinggian di atas permukaan laut 2.000 meter atau lebih, dan/atau ;

3. kawasan hutan yang mempunyai lereng lapangan $45 \%$ atau lebih, dan/atau.

Perlindungan terhadap kawasan bergambut dilakukan untuk mengendalikan hidrologi wilayah, yang berfungsi sebagai penambah air dan mencegah banjir, serta melindungi ekosistem yang khas di kawasan yang bersangkutan. Kriteria kawasan bergambut adalah tanah bergambut dengan ketebalan tiga meter atau lebih yang terdapat di bagian hulu sungai dan rawa. 
Perlindungan terhadap kawasan resapan air dilakukan untuk memberikan ruang yang cukup bagi peresapan air hujan pada daerah tertentu untuk keperluan penyediaan kebutuhan air tanah dan penanggulangan banjir, baik untuk kawasan bawahannya maupun kawasan yang bersangkutan. Kawasan resapan air memiliki kriteria sebagai berikut :

a. Curah hujan dengan intensitas tinggi, dan atau ;

b. Struktur tanah yang mudah meresapkan air dan bentuk geomorfologi yang mampu meresapkan air secara besar - besaran.

Perlindungan terhadap sempadan pantai dilakukan untuk melindungi wilayah pantai dari kegiatan yang mengganggu kelestarian fungsi pantai. Sempadan pantai mempunyai kriteria daratan sepanjang tepian yang lebarnya proporsional dengan bentuk dan kondisi fisik pantai minimal 100 (seratus) meter diukur dari titik pasang tertinggi kearah darat.

Perlindungan terhadap sempadan sungai dilakukan untuk melindungi sungai dari kegiatan manusia yang dapat mengganggu dan merusak kualitas air sungai, kondisi fisik pinggir dan dasar sungai serta mengamankan aliran sungai. Sempadan sungai ditetapkan dengan kriteria sebagai berikut:

1. Sungai bertanggul

a. di luar kawasan perkotaan ditetapkan sekurang-kurangnya 5(lima) meter.

b. Di dalam kawasan perkotaan ditatapkan sekurang-kurangnya 3 (tiga) meter.

2. Sungai tidak bertanggul

a. Di luar kawasan perkotaan pada sungai besar ditetapkan sekurangkurangnya 100 (seratus) meter, sedangkan pada sungai kecil ditetapkan sekurang - kurangnya 50 (lima puluh) meter dari kiri kanan sungai ;

b. Di dalam kawasan perkotaan

- sungai yang mempunyai kedalaman tidak lebih dari 3 (tiga) meter ditetapkan sekurang - kurangnya 10 (sepuluh) meter ;

- sungai yang mempunyai kedalaman lebih dari 3 (tiga) meter ditetapkan sekurang - kurangnya 15 (lima belas) meter. 
c. Yang berbatasan dengan jalan atau tepi bahu jalan yang bersangkutan, dengan ketentuan konstruksi dan penggunaan jalan harus menjamin bagi kelestarian dan keamanan sungai serta bangunan sungai.

Sempadan sungai yang ditetapkan berdasarkan kriteria sebagaimana dimaksud di atas:

a. Untuk Sungai Bertanggul diukur dari kiri kanan kaki tanggul bagian luar sepanjang tanggul sungai ;

b. Untuk Sungai Tidak Bertanggul diukur dari titik banjir tertinggi kearah daratan.

Perlindungan terhadap kawasan sekitar mata air dilakukan untuk melindungi mata air dari kegiatan budidaya yang dapat merusak kualitas air dan kondisi fisik kawasan sekitarnya. Kawasan sekitar mata air ditetapkan dengan kriteria jarak sekurang-kurangnya dengan jari - jari 200 meter di sekitar mata air.

Perlindungan terhadap kawasan sekitar danau/waduk dilakuakn untuk melindungi danau/waduk dari kegiatan budidaya yang dapat mengganggu kelestarian fungsi danau/waduk. Kawasan sekitar waduk/danau ditetapkan dengan kriteria daratan sepanjang tepian waduk yang lebarnya proposional dengan bentuk dan kondisi fisik waduk antara 50 (lima puluh) sampai 100 (seratus) meter diukur dari titik pasang tertinggi kearah darat.

Kawasan sekitar rawa kriteria daratan sepanjang tepian rawa yang lebarnya proporsional dengan bentuk dan kondisi fisik rawa antara 50 (lima puluh) sampai 100 (seratus) meter diukur dari titik pasang tertinggi kearah darat.

Perlindungan terhadap kawasan suaka alam dilakukan untuk melindungi keaneka ragaman biota, tipe ekosistem, gejala dan keunikan alam bagi kepentingan plasma nutfah, ilmu pengetahuan dan pembangunan pada umumnya. Kawasan Suaka alam terdiri dari :
a. Cagar alam ;
b. Suaka Margasatwa ;
c. Hutan Wisata ;
d. Daerah perlindungan plasma nutfah ;
e. Daerah pengungsian satwa. 
Kriteria cagar alam adalah :

a. Kawasan yang ditunjuk mempunyai keanekaragaman jenis tumbuhan dan satwa dan tipe ekosistemnya;

b. Mewakili formasi biota tertentu dan / atau unit-unit penyusun;

c. Mempunyai kondisi alam, baik biota maupun fisiknya yang masih asli dan tidak atau belum diganggu manusia;

d. Mempunyai luas dan bentuk tertentu agar menunjang pengelolaan yang efektif dengan daerah menyangga yang cukup luas;

e. Mempunyai ciri khas dan dapat merupakan satu-satunya contoh disuatu daerah serta kebenarannya memerlukan upaya konservasi.

Kriteria suaka margasatwa adalah :

a. Kawasan yang ditunjuk merupakan tempat hidup dan perkembanganbiakan dari suatu jenis satwa yang perlu dilakukan upaya konservasinya;

b. Memiliki keanekaragaman dan populasi satwa yang tinggi;

c. Merupakan tempat dan kehidupan bagi jenis satwa migran tertentu;

d. Mempunyai luas yang cukup sebagai habitat jenis satwa yang bersangkutan.

Kriteria Hutan Wisata adalah :

a. Kawasan yang ditunjuk memiliki keadaan yang menarik dan indah baik secara alamiah maupun buatan manusia;

b. Memenuhi kebutuhan manusia akan rekreasi dan olah raga serta terletak di pusat-pusat pemukiman penduduk;

c. Mengandung satwa buru yang dapat dikembang-biakan sehingga memungkinkan perburuan secara teratur dengan mengutamakan segi rekreasi, olah raga dan kelestarian satwa;

d. Mempunyai luas yang cukup dan lapangnya tidak membahayakan.

Hutan Wisata sebagaimana ditetapkan dengan kriteria sebagai berikut :

a. Kawasan yang ditunjuk mempunyai keadan yang menarik dan indah baik secara alamiah maupun buatan manusia ;

b. Memenuhi kebutuhan manusia akan rekreasi dan olah raga serta terletak dekat pusat - pusat pemukiman penduduk ; 
c. Mengandung satwa baru yang dapat dikembangbiakkan sehingga memungkinkan perburuan secara teratur dengan mengutamakan segi rekreasi, olah raga dan kelestarian satwa ;

d. Mempunyai luas yang cukup dan lapangan tidak membahayakan.

Kriteria Derah Perlindungan Plasma Nutfah adalah :

a. Areal yang ditunjuk memiliki jenis plasma nutfah tertentu yang belum terdapat didalam kawasan konservasi yang telah ditetapkan;

b. Merupakan areal tempat pemindahan satwa yang merupakan tempat kehidupan baru bagi satwa tersebut;

c. Mempunyai luas cukup dan lapangannya tidak membahayakan.

Daerah Pengungsian Satwa ditetapkan sebagai berikut :

a. Areal yang ditunjuk merupakan wilayah kehidupan satwa yang sejak semula menghuni areal tersebut ;

b. Mempunyai luas tertentu yang memungkinkan berlangsungnya proses hidup dan kehidupan serta perkembangbiakan satwa tertentu.

Perlindungan terhadap kawasan suaka alam laut dan perairan lainnya dilakukan untuk melindungi keaneka ragaman biota, tipe ekosistem, gejala dan keunikan alam bagi kepentingan plasma nutfah, keperluan pariwisata dan ilmu pengetahuan. Kawasan suaka alam laut dan perairan lainnya adalah kawasan berupa perairan laut, perairan darat, wilayah pesisir, muara sungai, gugusan karang dan atol yang mempunyai ciri khas berupa keragaman dan atau keunikan ekosistemnya.

Perlindungan terhadap kawasan pantai berhutan bakau dilakukan untuk melestarikan hutan bakau sebagai pembentuk ekosistem hutan bakau dan tempat berkembang biaknya berbagai biota laut disamping sebagai pelindung pantai dan pengikisan air laut serta pelindung usaha budidaya dibelakangnya. Kawasan pantai berhutan bakau ditetapkan dengan kriteria jarak minimal 130 kali nilai rata-rata perbedaan air pasang tertinggi dan terendah tahunan diukur dari garis air surut terendah kearah darat.

Perlindungan terhadap taman nasional, taman hutan raya dan taman wisata alam dilakukan untuk pengembangan pendidikan, rekreasi dan pariwisata serta 
peningkatan kualitas lingkungan sekitarnya dan perlindungan dari pencemaran. Kriteria taman nasional, taman hutan raya dan taman nasional dan wisata alam adalah kawasan berhutan atau bervegetasi tetap yang memiliki tumbuhan dan satwa yang beragam, memiliki arsitektur bentang alam yang baik dan memiliki akses yang baik untuk keperluan pariwisata.

Perlindungan terhadap kawasan rawan bencana alam dilakukan untuk melindungi manusia dan kegiatannya dari bencana yang disebabkan oleh alam maupun secara tidak langsung oleh perbuatan manusia. Kawasan Gerakan Tanah ditetapkan dengan kriteria kawasan yang mempunyai sifat tanah lunak, gembut dengan ketebalan lebih dari 1 meter dan mempunyai kelerangan lebih dari $15 \%$ serta merupakan daerah patahan. Kawasan rawan banjir ditetapkan dengan kriteria kawasan yang mempunyai ketinggian permukaan tanah lebih rendah dari permukaan laut dan atau sungai. Kawasan letusan gunung berapi ditetapkan dengan kriteria daerah yang terletak di lereng gunung yang masih aktif.

\section{Lokasi Kawasan Lindung}

Lokasi kawasan lindung untuk Kabupaten atau Kota dinyatakan dalam peta dengan tingkat ketelitian skala 1: 50.000 sebagai lampiran yang tidak terpisahkan dari Peraturan Daerah yang bersangkutan.

Pengelolaan kawasan lindung disesuaikan dengan kondisi, potensi dan kemampuan daerah. Di dalam kawasan lindung dilarang melakukan kegiatan budidaya, kecuali yang tidak mengganggu fungsi lindung. Di dalam kawasan suaka alam dan kawasan cagar budaya dilarang melakukan kegiatan budidaya apapun, kecuali kegiatan yang berkaitan dengan fungsinya, dan tidak mengubah bentuk alam, kondisi penggunaan lahan, serta ekosistem alam yang ada.

Kegiatan budidaya yang sudah ada di kawasan lindung yang mempunyai dampak penting terhadap lingkungan hidup dikenakan ketentuan-ketentuan yang berlaku sebagaimana dimaksudkan dalam Peraturan Pemerintah Nomor 27 Tahun 1999 tentang Analisis Mengenai Dampak Lingkungan. Apabila menurut Analisis Mengenai Dampak Lingkungan kegiatan budidaya mengganggu fungsi lindung 
harus dicegah perkembangannya dan fungsi sebagai kawasan lindung dikemblikan secara bertahap.

Dengan tetap memperhatikan fungsi lindung kawasan yang bersangkutan di dalam kawasasn lindung dapat dilakukan penelitian, eksplorasi mineral dan air tanah serta kegiatan lain yang berkaitan dengan pencegahan bencana alam. Apabila ternyata di kawasan lindung terdapat indikasi adanya deposit mineral dan air tanah atau kekayaan alam lainnya yang bila diusahakan bernilai amat berharga bagi negara, maka kegiatan budidaya di kawasan lindung tersebut dapat diizinkan sesuai dengan ketentuan peraturan perundang-undangan yang berlaku.

Pengelolaan kegiatan budidaya dilakukan dengan tetap memelihara fungsi lindung kawasan yang bersangkutan. Apabila penambangan bahan galian dilakukan, penambang bahan galian tersebut wajib malaksanakan upaya perlindungan terhadap lingkungan hidup dan melaksanakan rehabilitasi daerah bekas penambangan sehingga kawasan lindung dapat berfungsi kembali.

Pengendalian pemanfaatan ruang di kawasan lindung meliputi kegiatan pemantauan, pengawasan dan penertipan. Pengendalian dilaksanakan secara terpadu dan lintas sektoral melalui Tim Pengelola dan Pengendalian Kawasan Lindung yang ditetapkan oleh Penguasa Daerah.

Setelah Draft Perda disyahkan menjadi Perda dan telah disosialisasikan ke masyarakat maka tindakan yang tidak kalah penting adalah penegakan hukum dari PERDA ini. Penegakan hukum berkaitan erat dengan kemampuan aparatur dan kepatuhan warga masyarakat terhadap PERDA ini, yang meliputi bidang hukum administrasi, pidana.serta perdata. Penegakan hukum merupakan upaya mencapai ketaatann terhadap peraturan dan persyaratan dalam ketentuan hukum yang berlaku secara umum dan individual, melalui pengawasan dan penerapan sanksi administrasi, kepidanaan dan keperdataan.

Penegakan hukum dapat dilakukan secara preventif dan represif, sesuai dengan sifat dan efektifitasnya terhadap perbutan yang melanggar PERDA ini setelah diundangkan. Penegakan hukum yang bersifat preventif berarti bahwa pengawasan aktif dilakukan terhadap kepatuhan kepada peraturan, tanpa kejadian langsung yang menyangkut peristiwa kongkret yang menimbulkan sangkaan 
bahwa peraturan hukum telah dilanggar. Intrumen bagi penegakan hukum preventif adalah penyuluhan, pemantauan dan penggunaan kewenangan yang sifatnya pengawasan. Dengan demikian penegakan hukum yang dilakukan secara terpadu dan lintas sektoral melalui Tim Pengelola dan Pengendalian Kawasana Lindung yang ditetapkan oleh Penguasa Daerah guna mencegah terjadinya pelanggaran dari PERDA ini.

Penegakan hukum yang bersifat represif dilakukan dalam hal perbuatan yang melanggar PERDA ini. Pelanggaran terhadap PERDA ini dapat dilakukan sanksi admistrasi, pidana dan perdata. Dalam PERDA ini sanksi administrasi mempunyai fungsi instrumental, yaitu pengendalian perbuatan terlarang, di samping itu ditujukan kepada kepentingan yang dijaga oleh ketentuan yang dilanggar tersebut. Beberapa jenis sarana penegakan hukum administrasi adalah sebagai berikut:

(1) Gubernur/Bupati/Wali Kota berwenang melakukan paksaan terhadap penanggung jawab usaha dan atau/ kegiatan untuk mencegah dan mengakhiri terjadinya pelanggaran serta menanggulangi akibat yang ditimbulkan oleh suatu pelanggaran, melakukan tindakan penyelamatan, penanggulangan, dan / atau pemulihan atas beban biaya dari penanggung jawab usaha dan atau kegiatan sebanyak-banyaknya Rp. 50.000.000,00 (lima puluh juta rupiah), kecuali ditentukan lain berdasarkan peraturan perundang-undangan yang berlaku ;

(2) Gubernur/Bupati/Wali Kota berwenang pula melakukan penarikan uang paksa sebanyak-banyaknya Rp. 50.000.000,00 (lima puluh juta rupiah) ;

(3) Paksaan pemerintahan sebagaimana dimaksud pada ayat (1) didahului dengan surat perintah Gubernur/Bupati/Wali Kota.

Penegakan hukum Admistrasi ini dilakukan oleh Tim pengelola dan Pengendali Kawasan Lindung dan Penyidik Pegawai Negeri Sipil yang langsung dibawah Gubernur/Bupati/Wali Kota dan berkoordinasi dengan instansi terkait lainnya.

Penindakan secara pidana umumnya selalu mengikuti pelanggaran peraturan yang biasanya tidak dapat meniadakan akibat pelanggaran tersebut. Ketentuan pidana bertujuan untuk menghukum si pelanggar agar jera. 
"Pelanggaran terhadap ketentuan - ketentuan dalam Peraturan Daerah ini adalah tindak pidana pelanggaran dan di ancam dengan pidana kurungan paling lama enam bulan dan/ atau denda sebanyak-banyaknya Rp.5.000.000,- (lima juta rupiah) dengan atau tidak merampas barang tertentu untuk daerah, kecuali jika ditentukan lain dalam peraturan perundang-undangan”.

Sedangkan aparat penegak hukumnya adalah sebagai berikut:

a. Penyidik Pegawai Negeri Sipil (PPNS)

b. Polisi

c. Jaksa

d. Hakim

Mengenai penegakan hukum perdata adalah upaya penyelesaian sengketa perdata dengan cara gugatan perdata untuk memperoleh ganti kerugian bagi korban akibat perbuatan melawan hukum oleh seseorang, badan hukun atau Pemerintah Daerah.

\section{Penutup}

Hal yang tidak kalah penting adalah sosialisasi dan penegakan hukum PERDA itu sendiri. Sosialisasi PERDA akan berdampak pada kesadarn masyarakat terhadap kepatuhan PERDA tersebut, sehingga perbuatan masyarakat akan sesuai dengan harapan kita (sesuai dengan PERDA). Penegakan hukum amat tergantung dari aparat penegak hukum itu sendiri dan kesadaran masyarakat. Apabila aparat penegak hukumnya disiplin dan penuh dedikasi maka kemungkinan KKN amat kecil dan PERDA akan terasa efektif, sehingga banjir dapat dicegah.

\section{Daftar Pustaka}

Lubis, M. Solly, Landasan dan Teknik Perundang-Undangan, Penerbit Alumni, Bandung, 1989.

Pratondo, B.J., Sistem Pengendalian Banjir Di Jabotabek, Makalah Falsafah Sains, Program Pasca Sarjana/S3 IPB, 2 Desember 2002. 
Purbacaraka, Purnadi dan Soerjono Soekanto, Perihal Kaedah Hukum, Penerbit Alumni, Bandung, 1979.

Ranggawidjaja, Rosjidi, Pedoman Teknik Perencanaan Peraturan PerundangUndangan, Penerbit Cita Bhakti Akademika, Bandung, 1996.

Syarif, Amiroeddin, Perundang-Undangan, Dasar,Jenis dan Teknik Membuatnya, Penerbit Bina Aksara, Jakarta, 1987.

Berita KAI/Kemitraan Air Indonesia, 5 Februari 2004 - 11:47

Berita KAI/Kemitraan Air Indonesia, 5 Februari 2004 - 11:49

Kepres Nomor 32 Tahun 1990 tentang Pengelolaan Kawasan Lindung 